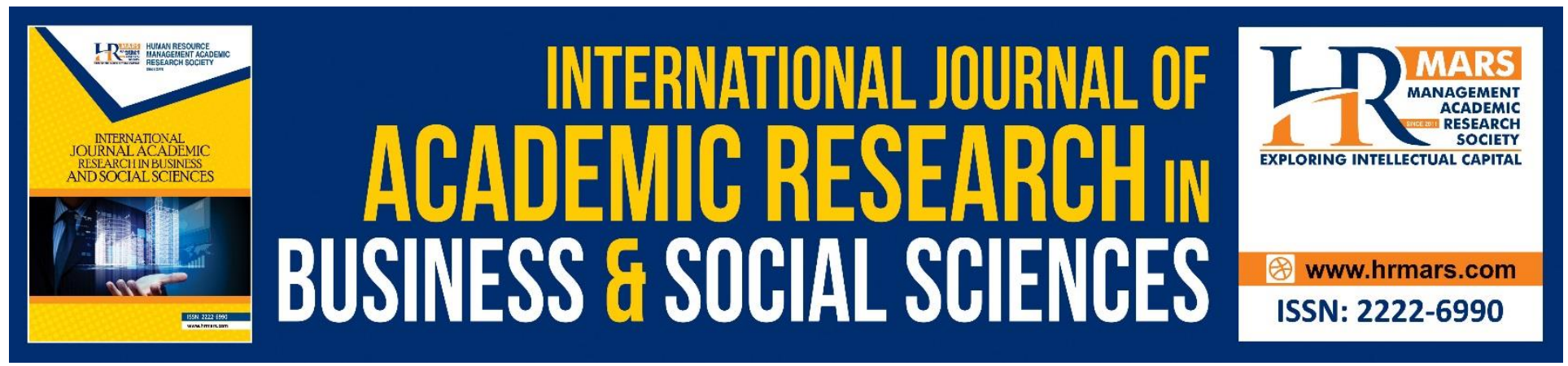

\title{
Guidelines of Fiqh For Sharia-Compatible Football Watching
}

\author{
Basri Ibrahim, Muhammad Ammar Firhan
}

To Link this Article: http://dx.doi.org/10.6007/IJARBSS/v9-i3/5687

DOI: $\quad 10.6007 /$ IJARBSS/v9-i3/5687

Received: 26 Feb 2019, Revised: 19 March 2019, Accepted: 27 Mar 2019

Published Online: 12 April 2019

In-Text Citation: (Ibrahim \& Firhan, 2019)

To Cite this Article: Ibrahim, B., \& Firhan, M. A. (2019). Guidelines of Fiqh For Sharia-Compatible Football Watching. International Journal of Academic Research in Business and Social Sciences, 9(3), 348-361.

Copyright: (C) 2019 The Author(s)

Published by Human Resource Management Academic Research Society (www.hrmars.com)

This article is published under the Creative Commons Attribution (CC BY 4.0) license. Anyone may reproduce, distribute, translate and create derivative works of this article (for both commercial and non-commercial purposes), subject to full attribution to the original publication and authors. The full terms of this license may be seen at: http://creativecommons.org/licences/by/4.0/legalcode

Vol. 9, No. 3, 2019, Pg. 348 - 361

http://hrmars.com/index.php/pages/detail/IJARBSS

JOURNAL HOMEPAGE

Full Terms \& Conditions of access and use can be found at http://hrmars.com/index.php/pages/detail/publication-ethics 


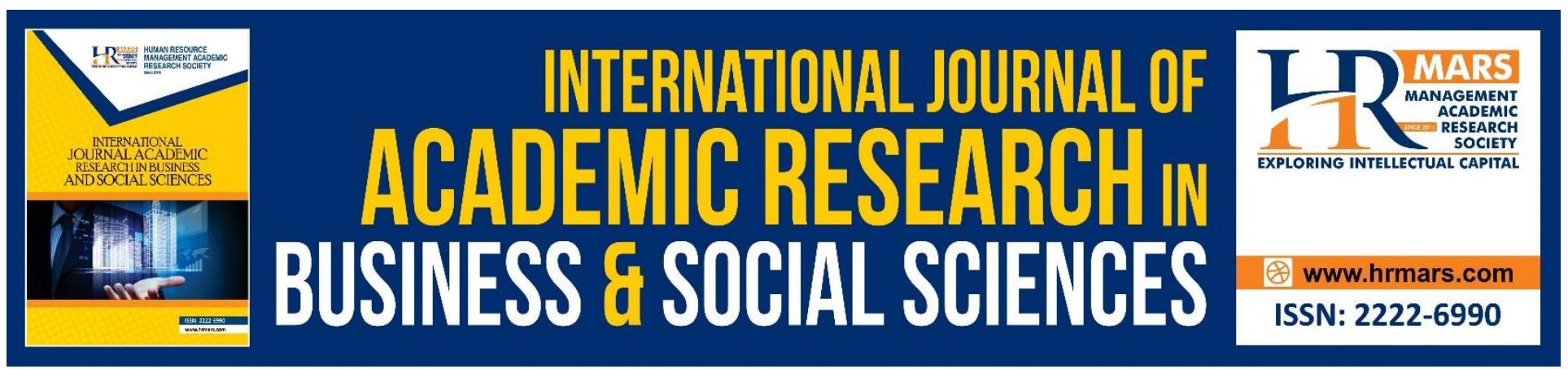

\title{
Guidelines of Fiqh For Sharia-Compatible Football Watching
}

\author{
Basri Ibrahim, Muhammad Ammar Firhan \\ Global Wisdom Academy, Universiti Islam Malaysia, Cyberjaya, Malaysia/ Faculty of Islamic \\ Contemporary Studies, Universiti Sultan Zainal Abidin, Terengganu, Malaysia. \\ Global Wisdom Academy, Universiti Islam Malaysia, Cyberjaya, Malaysia.
}

Corresponding Author: drbasr67@gmail.com.

\begin{abstract}
Football game is not silent from supporters from around the world, including Islamic countries. While watching football, there are many types of disposition shown by the viewers. Some display calm reaction and not less who dispose violent reaction. Such reactions frequently lead to riot and destruction to property of government. Sometimes, it is caused by dissatisfaction of the viewers towards performance quality of the referee and sometimes towards player of their team or of the opponent. Such uncontrolled behaviours displayed by certain viewers during the watching of football match either at stadium or home need clear guidelines to control them that they will comply to sharia and will not contribute to damage of properties and fight between them, which all will be a loss to the country. The purpose of this article to be brought forward is to explain the fiqh guidelines of sharia-compatible football watching, as a formula of reducing fight incidents and property damage during football watching. It also aims to protect the image of Muslim community as a highly-civilised community with good moral conduct either in happiness or in sadness. Method of this study was based on qualitative study. Data were collected from documentation study by referring to books related to tafsir, sunnah, classical fiqh books, principles of Islamic jurisprudence, contemporary fiqh, current fatwas and views of contemporary scholars, surveys, observation and also interviews. Data were collected, analysed and elaborated through inductive deductive and comparative methods to get appropriate result compatible with determined research objective. This research found that fiqh guidelines of football watching are of three aspects which are faith (aqidah), rituals of worship (ibadah) and moral disposition (akhlak). Faith focuses more on someone's undivided dependence to Allah SWT. Rituals of worship emphasise guarding of obligatory to not be ignored. Moral disposition stresses more on keeping in line the actions at the stadium during the watching of a football match, to ensure the high civilisation and noble moral disposition.
\end{abstract}

Keywords: Current Fatwa, Classical Fiqh, Fiqh of Watching, Principles of Islamic Jurisprudence, ShariaCompatible 


\section{Introduction}

Football watching becomes an interest of most of the Malaysian citizens either they are Muslim or non-Muslim. It is not only watched at the stadium but also at home either as live or delayed broadcast. However, football match does not always end with expected result that satisfies the supporters of both competing teams, indeed it also ends with tragedy.

There are football matches polluted with certain actions of the supporters which sometimes invite damage of public property, fight, utterance of bad words to supporters of the opponent team, referee, linesmen, goalkeeper and others, as explained in the first chapter. It rises as a result of dissatisfaction by the supporters of certain team in a certain football match resulting in their team facing big loss or loss at the final level. The continuity of the happening tragedy sometimes causes the state football association to face certain fine by FAM.

Besides that, the survey discussed in this study found that understanding and practice of football supporters in this country either at stadium or at home on the prohibited and allowed actions by Islamic laws during football watching, were at the highest level but the mean of understanding was higher than for the practice. This indicates that respondents' practice was no aligned with their knowledge on the sharia-compatible fiqh of football watching.

As known for now, there is no such guidelines made by any party or related ministry regarding the fiqh of football watching in this country which is really sharia-compatible. Therefore, this study would like to bring forward the guidelines of sharia-comaptible figh of football watching which can be referred not just by the Ministry of Youth and Sports and groups organising football match, but also by the football fans in this country. With that, it is hoped that it can produce football fans of high discipline and moral disposition during the foorball watching, besides not forgetting to concern on the faith and rituals of worship either at stadium or home. The question is what is stated as the fiqh guidelines of football watching?

The purpose of this article to be brought forward is to explain on the fiqh guidelines of shariacompatible football watching as a reference for the Muslim football fans in this country during football watching either at stadium or home. With this, it is hoped that it can facilitate the authorities in reducing unwanted incidents during any proceeding match such as damage of public property, fight, quarrel, stadium pollution and others. These all harm the country besides tarnishing the good name of Muslim community itself. With this, it also can produce highly-civilised viewers of football match, avoiding destruction of public property and protect the image of Muslim community from being tarnished by irresponsible actions which should not be done by them during the watching of any football match, even though they are dissatisfied with the match.

Writings on game and football match have been done by contemporary scholars. Among them is Uthaimin (2017) commenting on the football game issue through website of Islamic fatwa question and answer which is http://fatwa.islamweb.net/fatwa, Yusoff (2015) in Journal of GEOGRAFIA Online TM Malaysian Journal of Society and Space 11 issue 13 (72 - 78) 72 on the misconducts among football viewers in Malaysia, al-Qalmuni (2011) in the work titled Kurrah alQadam Wa Akhawatuha. He talked on the history of football and its entry into Muslim countries and the harms emerging from the football game itself. Masyhur Ibn Hasan Ali Salman (1998) elaborated in Kurrah al-Qadam Bayna al-Masalih Wa al-Mafasid al-Syar'iyyah in the football game and focused on the aspects of needs and harms rising caused by the game. Al-Qaradawi (1996) commented on 
games in his book al-Islam Wa al-Fan. In the book, he touched on the games generally without focusing in football game only and ethics regarding football watching. The same subject was also touched by al-Qaradawi (2006) in his work Fiqh al-Lahwi wa al-Tarwih. However, the above writings and researches did not touch on comprehensive serious study on sharia-compatible figh of football watching.

\section{Research Methodology}

This writing was based on qualitative study. Data were collected from documentation study by referring to books related to tafsir, sunnah, classical figh books, principles of Islamic jurisprudence, contemporary figh, current fatwas, views of contemporary Islamic scholars, surveys, observations and interviews. The collected data were analysed and explained through comparison method to obtain appropriate results aligned with the determined study objective.

\section{Findings}

Contemporary scholars permit football game and match. Among them are:

a. Fatwa Committee of Saudi Arabia Government (al-Ghamidi 1429H:187).

b. Muhammad Salih Uthaimin (https://islamqa.info, 2010).

c. 'Abd al-Aziz bin 'Abdullah Ali al-Syeikh (http://www.ajurry.com, 2018).

d. Abdullah al-Faqih (http://www.ahlalhdeeth.com, 2018).

e. 'Ubaid bin Abdullah al-Jabiri (http://www.ajurry.com, 2018).

f. Muhammad Nasir al-Din al-Albani (http://www.ahlalhdeeth.com, 2018).

g. al-Qaradawi (2016:72-73).

\section{Conditions of Permission for Football Watching}

The above scholars who allow watching of football match put that several conditions to be observed by the viewers either at stadium, coffee shops or home are:

a. The watching does not prevent somebody from performing prayer, does not expose aurat of the players and does not create fight or hostility.

b. The watching does not void any obligation or lead to any forbidden action (al-Ghamidi, 1429H:187).

c. The watching does not cause mockery and insult between the supporters of competing opposing team.

d. The watching does not bring the large needs of sharia into negligence (al-Qaradawi, 2006:7273).

e. The watching still makes someone steadfast to noble moral disposition and manner. 
INTERNATIONAL JOURNAL OF ACADEMIC RESEARCH IN BUSINESS AND SOCIAL SCIENCES

Vol. 9, No. 3, March, 2019, E-ISSN: 222 2-6990 ¿ 2019 HRMARS

f. The watching does not plunge someone into fanaticism to a certain team until it leads into hatred and hostility with the opponent (http://www.ajurry.com, 2018).

\section{Reasons of Permitting the Watching of Football Game with Condition}

Among the reasons posed by this group are:

a. There is no authentic and concrete evidence to forbid the football watching either from alQuran or al-Sunnah while saying something forbidden must be based berdasarkan dalil yang bersifat sahih dan sarih.

b. Football game is one of the game that involves community culture and custom, in which the original ruling related to it is harus, until there is evidence that makes it haram.

c. Most of the scholars who put football watching as haram, do not refer to the football match itself. Instead, they relate it to other factors either externally or internally.

d. Football match still does not cause any large harm compared to the benefits gained from it.

e. Football game and match has occurred throughout the whole world including in Muslim countries in which their scholars forbid the football game itself. Muslims might not agree to do something bad according to Islam.

\section{Definition for Fiqh of Football Watching}

Fiqh of sharia-compatible football watching brings a meaning of deep understanding about the manners and ethics related to watching of a certain game or match of football based on sharia needs, either at stadium or at home.

\section{Scope for Fiqh of Sharia-Compatible Football Watching}

Scopes of guidelines for fiqh of football watching encompasses three aspects which are akidah (faith), ibadah (rituals of worship) and also akhlak (moral disposition).

\section{Guidelines for Fiqh of Sharia-Compatible Football Watching}

Guidelines for sharia-compatible football watching includes three aspects which are akidah (faith), ibadah (rituals of worship) and also akhlak (moral disposition).

\section{Akidah aspect}

Akidah aspect encompasses:

a. Viewers cannot show their anger when the supported team faces loss as they are denying the qadak and qadar (destiny) of Allah. This is because denying the qadak and qadar (destiny) of Allah will make someone infidel. Qadak is the commencement of what that has been destined 
by Allah SWT about all the things happening in real life since the beginning of time. Meanwhile, qadar is everything destined by Allah since the beginning of time (al-Asyqar, 2005:23-24). Both relate to the administration of Allah SWT and the creations do not have power of it at all. Loss and win are not more than the regular custom happening in a football match.

b. Viewers should believe that Allah SWT bestows win and loss to any competing football team that He wants. Will of Allah SWT cannot be denied at all, instead it must be born with acceptance and open heart. If any supported team gains the winning, they must show gratitude and if they face loss, they must be patient and cannot lose hope at all.

c. Viewers should believe that the win comes with help of Allah SWT besides getting the need of taking the reasons. They cannot be confident that the winning hundred-percent only comes from the preparation and energy strength of the team players that they support. This is because if Allah SWT does not will the team to win, the team would still not get the winning, even though the preparation has been provided properly.

d. Viewers should increase prayers with a sincere heart as submitting prayer to Allah SWT with a sincere heart is one of the reasons of getting success in anything including the football match. Moreover, the prayer itself is a form of worship and destiny of Allah SWT cannot be rejected except through prayer.

e. Viewers cannot glorify and idolise their favourite football player more than the limit, as the action will cause the glorified and idolised player becomes arrogant and boastful and the action will expose them to the idolatry of person until they put them at the same level with the glorification of God of the Universe, which at once also trace a way into idolatry of people which has happened in the human history in the time of previous prophets. If they are still to be glorified, it must be in a moderate frame that does not ignore the sharia commandments and not breach all its prohibitions.

f. Spectators cannot get shaman's service at all to make sure that the match goes well. This is because the shaman does not know anything about the unseen things and what is spoken is just a mere guess. The coming of rain is entirely Allah's destiny. The highest level that they may strive for is to get opinion from the meteorological department to observe the climate at the night when a certain match is held, to provide proper preparation involving raincoats, umbrellas and also the consumption of particular medicines.

g. Viewers cannot get shaman's service, spell incantation and amulet to get the winning for the supported team. Because the winning is not determined by the shaman and not in shaman's hand, but it is determined by Allah SWT. In spite of that, what can be done by them is by adding up prayers to Allah so that He bestows their supported team with a winning, while the supported team must prepare themselves with various training, skills regarding the attack, breaking an attack and also scoring the ball into the opponent's goal. 
h. Spectators should always submit and surrender to Allah SWT for any circumstances that will happen and believe that it carries along particular goodness ad wisdom behind the winning or loss faced by the supported team. By doing that, it would vanish the frustration or ecstasy of them. This is because, in this world, human cannot escape from happiness and sadness which closely relate to qadak dan qadar of Allah as explained above.

\section{Ibadah Aspect}

Ibadah aspect includes:

a. Viewers cannot neglect the obligation of performing the obligatory prayer along the stay at stadium to witness a football match, as performing obligatory prayer is compulsory and cannot be abandoned at all. Moreover, facilities for performance of prayer have been provided at the stadium. If the praying area is quite narrow and difficult to accommodate the number of people at a certain time, prayer can be commenced at any clean area and during the prostration, they can prostrate on the flag brought to support a team, if there is no praying mat, as long as the flag is not contaminated with any najis (filth). Obligatory prayers are the pillars of religion and one who abandons it means that he crushes the religion. People who do not perform the prayer have actually break the tie from Allah, as the prayer is actually a tie of relationship between a human and his God.

b. Viewers are not allowed to abandon prayer at all if they cannot perform ablution when there is no water due to reason of water supply cut at the stadium. This is because if someone could not use water, the prayer must be performed through tayammum utilising ash even though with the ash at the stadium pillars, as long as it is ensured pure (al-Rafi'i, 1995.2:119). If someone cannot perform ablution due to lack of water or tayammum due to lack of ash, they need to perform prayer of period respect, to avoid from the prayer being voided just as that. The performed prayer must be reperformed at other time (al-Zuhaili, 1985:1:451). Individual who could not perform ablution and also utilisation of ash is known as faqid al-tahurayn (alZuhaili,1:111)

c. Viewers who travel a long journey to watch and witness football match of over two marhalah (81 kilometer) (al-Bugha, et.al, 1992.1:190), are allowed to perform prayer in the form of qasar (shortened), jamak (combined) or qasar and jamak at the same time, as they are counted as travellers and the travel they embark on is the permitted travel as it is with good intention. This is because football is a permitted game in Islam according to majority of the scholars.

d. Spectators cannot wear any aurat-exposing attire, thin attire, tight and showing the shape of aurat or obscene attire during football watching at the stadium. During celebration for the winning of the supported team, there should not be action that can expose or visualize aurat. Female aurat in front of marriageable male is the whole body excluding the face and the two 
palms, while male aurat in front of non-marriageable female is the parts between the navel and the knees. Male aurat in front of marriageable female is the whole body except parts that are usually exposed while working which are the face, hands, feet and others (al-Zuhaili, 1985.1:589).

e. Viewers cannot shave part of their head and keep some other part, either at the stadium or outside of it as imitating the action by player of the supported team or supporters of opponent team. The action is more to qaza' which is forbidden by Islam, for defacing the head shape and someone's face without any reasonable cause. Even though viewers who do it do not intend it as something compulsory to be done but as a form of support for the favoured team. Showing support is unreasonable through shaving of part of head and keeping other part, instead it can done through motivation and supportive words which do not violate the rules of football to the players of supported team.

f. Viewers reasonably cannot paint their faces with various colours during the watching of football match at the stadium as the action is more to imitation of western football fans' culture, which is not allowed in Islam. In spite of that, viewers can come to the stadium with unpainted original face and express their support to the favoured team. Painting face with variety of colours does not change the winning or loss toward the supported team, instead it is scary for some people.

g. Spectators can come to the stadium to witness a football match with fiancée or lover but cannot be in just two of them but must be with other mahram. This is to prevent trials and misconducts while at the stadium or on the way home sending the lover of fiancée home. In Islam, every reason that becomes the factor of a certain misconduct is prohibited and forbidden to be done.

h. Viewers should not sit at the stadium in mingling condition between male and female and in the crowded situation. Instead, they should sit separately between male and female. In this case, the administrative personnel of stadium should play their role to separate the seats between male and female by a rope or anything to divide between the viewers of different sexes. With that, any bad or immoral doing including sexual harassment could be avoided during the watching of a football match. That immoral action is possible to happen in the packed and thronging situation of the viewers and also while returning home after the football match at midnight. This is because there are some among the viewers who take advantage to stay overnight with the fiancée or lover at certain budget hotels.

i. Viewers should not leave sahur (pre-dawn meal) during the watching of football match which is broadcast during month of Ramadhan, especially the one involving the World Cup match. This is because eating sahur is a very encouraged practice for the people who want to fast the next day even though it is just an sunat (supplementary) fast. Leaving it means leaving a sunnah of Rasulullah SAW which is very encouraged for the Muslims to pratise it and also loss 
of reward eating the sahur. Besides that, eating sahur also helps someone to undergo fasting the next day more comfortably as it acts as a breakfast.

j. Viewers cannot bet or gamble during the watching and witnessing any football match, in any form to determine the winning team. This is in view of that gambling is prohibited in Islam as it wastes property and a useless act. It can create hostility among the gamblers. In addition, it also ruins the marriage institution and initiates disharmonious situation in the community. Moreover, it happens in the intense situation of organising programs to strengthen the family, relationship between husband and wife, and parent and children. Betting and gambling during the commencing football match is a culture of western football fans which is obligatory to be avoided and cannot be imitated.

k. Spectators cannot bring or drink alcoholic beverage such as liquor or drug at all, whether alone or with friends, and whether inside or outside of stadium, or at their own homes while watching a football match. It is countless of whether they do it in the intention of expressing joy or sorrow for the loss faced by the supported team. Drinking liquor and taking drug are also prohibited in Islam and those who do that are sinful. His is because the liquor and drug can damage and vanish the sanity of mind, while mind is obligatory to be protected from losing its judgement.

\section{Akhlak Aspect}

Akhlak Aspect includes:

a. Viewers cannot throng and defame the ticket sellers and public during the purchase of ticket, especially when purchasing limited tickets, even though they have come so early. This is because the thronging and defamation act towards the ticket seller especially when the ticket has run out in just a couple of hours, would not bring any benefit, as the ticket to be bought still runs out and the defamation act will hurt other people and bring sins. The ticket sellers only do their responsibility and when the ticket runs out, they cannot do anything. Viewers should guard their patience as much. Although they could not watch a football match at the stadium, they still have chance to watch it at the television screen either at home or restaurant. On the other hand, attitudes that must be shown by the viewers are queueing up properly to buy ticket and thanking the ticket seller after getting the wanted tickets. If they could not purchase the ticket as it has already runs out, bear in mind that God has decided for him to be unable of purchasing the ticket that day.

b. Viewers cannot insult or say obscene words towards the players and coaches of supported team and also of opponent team, if any incident happens on the filed during the match. This is because by insulting and vulgarising could not solve the happening incident. They should take positive attitude by leaving the happening incident to the wisdom of referee or management of both competing team to resolve it. Following the dissatisfaction feeling too 
much will create undesired incident more critically such as fight, damage of facility at the stadium and also properties of supporters for both competing teams.

c. Spectators should not insult or vulgarise cops, Federal Reserve Unit (FRU) and security personnel who are taking care of security at the stadium, who bullet to the mid of field to resolve any matter creating dissatisfaction to the commencing match. It also goes when a violent riot sparks. Cops and other security agencies only perform their task to calm down the viewers and protect public facilities from destruction. They do not involve with any incident on the play field and entirely cannot be blamed for the incident happening on the field. Their task should be respected. Due to that, if they command particular people to leave the stadium, they should obey it to prevent worse incidents from happening. Spectators should give proper cooperation to the security personnel to avoid fight and destruction to the stadium facilities and properties of government.

d. Spectators cannot insult or vulgarise at all player who fails to control the ball causing the opponent to grab the ball and strike it into the goal of supported team or the player fails to strike into the opponent's goal after he is close to the opponent's goal. In a football match, many possibilities might occur. Player losing the ball might be due many reasons such as cramping, wet field, downpours and others. Spectators watching the game is not the same at all as the player involved directly with the match on the field. Malay proverb says that, "Berat mata memandang, berat lagi bahu memikul" which means how heavy you see a person bearing the burden, it is heavier for the person who bears the burden itself.

e. Viewers should not make excessive noise during commencing football match until it disturbs other people, especially supporters of opponent team and the players playing on the field. It is undeniable that there are some certain forms of support allowed for the supporters to perform for the supported team such drum beating, bringing banners and state flag, wearing the jersey of supported team and others. However, it cannot be done fanatically, until the level of not focusing to the commencing football game but to the supporters of opponent team. For example, directing the noise sound to the supporters of opponent team and at once disturbing their concentration to their supported team. It visualises that their right to express support for their team is denied.

f. Spectators should not sit or be at the walking area of spectators in the stadium until they block the passing of entry and exit for the football supporters. This such action clearly disturbs people passing by whether they want to go to the toilet, leaving early or others. It is not denied that usually there is security guard on task of guarding the entry and exit of the stadium. However, sometimes crowding happens at the exit, when the spectators frustrated with a match act by going out of stadium earlier and cause the thronging to the pathway. Sometimes, there are viewers who leave earlier to avoid traffic jam after that. With that, the act of sitting at the pathway would definitely disrupts the exit movement of supporters for both competing teams and it is obviously an irrational act. 
g. Spectators should not throw mineral water bottles, drink cans, firecrackers, food wrappers an others to the mid of play field in stadium and outside of stadium. This is because it is included in the meaning of hurting other people and harming the players. Sometimes, it causes the play to be delayed for a moment to give time for the security personnel to remove the firecrackers and cans. Islam is a religion of no harm and prohibits its people from doing something harmful to others. The action pictures the attitude of irresponsible spectators and bad disposition which are far from the teaching of Islam.

h. Spectators should not hit or injure the supporters of other team due to misunderstanding or dissatisfaction when the supported team loses. In addition, they cannot hit the security personnel performing their task, referee, coaches and others. Instead, they should have more patience in facing any dissatisfaction regarding the witnessed football match and leave the incident to the authorities to solve it. Taking action of hitting supporters of opponent team or security personnel or referee, does not solve the problem, in fact it complicates it further. Such action according Malay proverb "bagaikan tikus membaiki labu" in which somebody who tries to repair something they do not know how to repair.

i. Spectators cannot bullet to the mid of field and create chaos, including hitting the players of opponent team, when he sees the opponent player injures the supported team. Instead, they should leave it to the security personnel on task to manage it. Spectators should believe that security personnel have their own methods of overcoming the misunderstanding that happens among football players. By taking action through bulleting into the mid of field and creating chaos would not solve the happening problem. Moreover, the viewers do not have authority in resolving the clash. Harm would definitely not be overcome by doing a same harm or larger than that.

j. Viewers cannot damage public transport, bus or stadium facilities, due to dissatisfaction for any match or judging quality made by a referee. Because by acting like that would not bring any benefit to the supporters of both competing teams and the country field of football. Despite, it tarnishes the good name of country football quality not just among the citizens, but also to the eyes of world football fans. The damage caused does not involve small cost, by it requires an enormous cost and takes a long duration to repair it. This means a lot of money should be withdrawn by the government for the repairing cost caused by actions of irresponsible viewers, instead of the cost used for other activities which are more beneficial for country and community.

k. Viewers cannot show long faces to wives, children and officemates for sorrow and sadness due to the loss of supported team, as football match is a match exposed to winning and loss. Sometimes, a particular supported team gains winnings, and other times it faces losses. This can be seen in at every time when national competition of football commences. It is not refuted that sadness due to loss of supported team is a nature, but expressing the sadness until the level of showing faces to the children, wife and officemates are too much. Overreaction in every matter is prohibited in Islam. 
I. Viewers should not show obscene signs to the player or supporters of opponent team. Showing vulgar signs while facing something signs a lack of noble manner. Noble people are those who always utter good words when speaking or talking even though he is being insulted by somebody and holding his anger. Carefulness in uttering words of speech especially during celebration of winning or facing loss is a sign of highly-civilised people and high level of manner. If the opponent team wins, they should congratulate and not show sour faces in front of them. Indeed, the congratulation itself indicates a high sportsmanship demanded by the nation and race.

m. Spectators cannot dance, jig and scream as they are possessed by the devil when their supported team wins or when they succeed of striking the ball into the opponent's goal. The act uncontrolled jigging, dancing and screaming is prohibited in Islam. It pictures someone to be insane. Joy due to success of the supported team to score goal is not prohibited, but the joy should not be expressed in the form of jigging, dancing and screaming without purpose. Instead, it should be expressed in the form of submitting their high gratitude to Allah SWT for giving strength to the supported team to strike the ball into the opponent's goal. Indeed, it is rational if the triumph and success celebrated through glorification and sought of forgiveness as the success might be part of God's bounty and by doing that, it will prevent someone from being delirious, arrogant and boastful. Besides that, the act of jigging, dancing and screaming with craze originates from the football supporter of western countries which should not be practised among Eastern community especially among Muslim supporters, who own high level of attitude upon bestowment of bounty.

n. Viewers should not make wild accusation to the coaches or players without complete and concrete evidence, when the supported team faces loss in a match, particularly in the final match. For example, accusation of match booking, truce with the opponent's coach, receiving bribe and others. If there is any hesitation on the possibility of match booking, bribery or anything, a decent report could be made at nearby police station. Police in collaboration with other agencies related to authority of state or national sport management will do investigation and take just action to involving individuals when they are really proven involved with the unhealthy activity. Accusing coaches, players and others with wild accusation, is more to backbiting that invites sins to the accusing individual himself, for keeping prejudice towards them.

o. Spectators should exit the stadium in a calm situation after the match has ended even though their supported team faces big defeat. They need to accept the defeat with a open heart by considering that luck is not with them. They should not create provocation towards opponent's team which could spark misunderstanding, quarrel and fight outside of the stadium. They should not come out of stadium in depression and anger while defaming coaches, referee, players and supporters of opponent team. All of that contradict with high level of sportsmanship. 


\section{Conclusion}

Guidelines of fiqh for sharia-compatible football watching consists of three main aspects which are akidah, ibadah and akhlak. In the akidah aspect, there are elements related to qadak and qadar of Allah, seeking of help from human like shaman or astrologer, heart rituals of worship like submission to Allah, firm belief in Allah as the One who bestows winning and loss and not depending on the skills owned by the creation, the need to multiply prayers to Allah of getting the winning to the supported team and acceptance of winning or loss with open heart.

In ibadah aspect, it involves obligation of performing obligatory prayer and for the who travels is allowed to perform jamak and qasar prayer if the travel reaches 81 kilometers and above, not wearing aurat-exposing and obscene attires, not shaving part of head and leaving the other part of it, not coming with fiancée without mahram, not sitting in stadium crowdedly between male and female, providing separate seats between male and female spectators, not abandoning sahur, not gambling and not bringing intoxicating beverage.

Akhlak aspect of it involves no thronging and insulting of ticket sellers when the ticket has run out, not insulting or vulgarising the players and coaches of supported team, and players and coaches of opponent team, cops, Federal Reserve Unit (FRU) and security guards who guard the security of stadium and football players who fail to control ball, not making noise excessively during the commencement of football match lading to disturbance towards other people, not sitting or being at the pathway of supporters in the stadium causing a block of entrance and exit pathway for the football supporters, not throwing mineral water bottles, drink cans, firecrackers, food wrappers, and others into the play field, not hitting or injuring supporters of other team due to misunderstanding or dissatisfaction, not bulleting into the mid of field and making chaos, including hitting the players of opponent team, not damaging public transport, bus and stadium facilities, not showing sour faces to wife, children and officemates for sorrow and sadness, not showing vulgar signs to the players or supporters of opponent team, not jigging, dancing and screaming as being possessed by the devil when the supported team wins, not making wild accusation to the coaches or players without complete an concrete evidence and coming out of the stadium peacefully.

These guidelines focus on the guard of a part from maqasid syariah which is to protect religion, which is the belief of ummah, life which is the continuity of ummah's life, property which is the source ummah's economic stability and dignity that pictures the personality and civilisation of ummah in the eyes of the world. This is because football watching which is happening now, is exposed to the matters derailing the faith, sins of backbiting, swearing and hitting of spectators subconsciously, damage of personal properties and fight and misunderstanding between the supporters of two competing team in action.

\section{Corresponding Author}

Basri Ibrahim, Jamalullail Professorial Chair, Global Wisdom Academy, Universiti Islam Malaysia, Cyberjaya, Malaysia/ Lectureur, Faculty of Islamic Contemporary Studies, Universiti Sultan Zainal Abidin, Terengganu, Malaysia..

Email: drbasr67@gmail.com.

\section{Acknowledgement}

Special thanks to the GWA, Universiti Islam Malaysia, Cyberjaya for funding the research. 
INTERNATIONAL JOURNAL OF ACADEMIC RESEARCH IN BUSINESS AND SOCIAL SCIENCES

Vol. 9, No. 3, March, 2019, E-ISSN: 222 2-6990 ¿ 2019 HRMARS

\section{References}

Ali, S.M. (1998). Kurrah al-Qadam Bayna al-Masalih Wa al-Mafasid al-Syar'iyyah. Lubnan: Dar Ibn Hazm.

Al-Asyqar, S.A. (2005). Al-Qada' wa al-Qadar. Jordan: Dar al-Nafa'is.

Al-Bugha, M.K.M.S.A. (1992). Al-Fiqh al-Manhaji ‘Ala Mazhab al-Imam al-Syafi'i Rahimahullah. Jil.1. Damsyiq: Dar al-Qalam.

Al-Ghamidi, Z.S.A.H.(1429H). Haqiqah Kurrah al-Qadam. N.p.

Hafizah Y \& P. S. (2015). Faktor-Faktor Yang Mempengaruhi Salah Laku Dalam Kalangan Penyokong Pasukan Bola Sepak Di Malaysia. GEOGRAFIA Online TM Malaysian Journal of Society and Space 11 issue 13 (72 - 78) 72. 5, ISSN 2180-2491.

Khairuldin, W. M. K. F. W. (2018). Fatwa Role in Education and Legal Dispute in Malaysia. International Journal of Academic Research in Progressive Education and Development, 7(4), 295-302.

Khairuldin, W. M. K. F. W., Embong, A. H., Anas, W.N.I.W.N., Mohd, H. \& Ismail, D. (2018). The Application of Technology in the Dissemination of Fatwas: A Study on Religious Institutions in Malaysia, International Journal of Civil Engineering and Technology, 9(7), 2018, pp. 15901596.

Al-Qalmuni, A.Z. (2011). Kurrah al-Qadam Wa Akhawatuha. T.pt.

Al-Qaradawi, Y .(2006). Fiqh al-Lahwi wa al-Tarwih. Cairo: Maktabah Wahbah.

Al-Rafi'i, S.A.G. (1998). Mukhtasar Majmu' Syarah al-Muhadhdhab. 1-8. Kingdom of Saudi Arabia: Maktabah al-Sawadi.

Al-Zuhaili, M. (2007). Al-Mu'tamad Fi al-Fiqh al-Syafi'i. Jil. 1. Damsyiq: Dar al-Qalam.

Al-Zuhaili, W.(1985). Al-Fiqh al-Islami wa Adillatuhu. Jil. 1. Beirut: Dar al-Fikr. 